\title{
Gender-dependent association of HSD11B1 single nucleotide polymorphisms with glucose and HDL-C levels
}

\author{
Luciane Viater Turek ${ }^{1}$, Neiva Leite ${ }^{2}$, Ricardo Lehtonen Rodrigues Souza ${ }^{1}$, Jovana Karoline Lima ${ }^{1}$, \\ Gerusa Eisfeld Milano ${ }^{2}$, Luciana da Silva Timossi ${ }^{2}$, Ana Claudia Vecchi Osiecki ${ }^{2}$, Raul Osiecki ${ }^{2}$ \\ and Lupe Furtado Alle ${ }^{1}$ \\ ${ }^{1}$ Departamento de Genética, Universidade Federal de Paraná, Curitiba, PR, Brazil. \\ ${ }^{2}$ Departmento de Educação Física, Universidade Federal de Paraná, Curitiba, PR, Brazil.
}

\begin{abstract}
In this study, we investigated the influence of two SNPs (rs846910 and rs12086634) of the HSD11B1 gene that encodes $11 \beta$-hydroxysteroid dehydrogenase type $1(11 \beta$-HSD1), the enzyme that catalyzes the conversion of cortisol to cortisone, on variables associated with obesity and metabolic syndrome in 215 individuals of both sexes from southern Brazil. The HSD11B1 gene variants were genotyped using the TaqMan SNP genotyping assay. Glucose, triglycerides, total cholesterol, HDL-cholesterol and LDL-cholesterol were measured by standard automated methods. Significant results were found in women, with carriers of the G allele of SNP rs12086634 having higher glucose levels than non-carriers. Carriers of the A allele of SNP rs846910 had higher levels of HDL-cholesterol. The involvement of both polymorphisms as independent factors in determining the levels of glucose and HDL-cholesterol was confirmed by multiple regression analysis $(\beta=0.19 \pm 0.09, p=0.03$ and $\beta=0.22 \pm 0.10, p=0.03$, respectively). Our findings suggest that the HSD11B1SNPs studied may indirectly influence glucose and HDL-cholesterol metabolism in women, possibly through down-regulation of the HSD11B1 gene by estrogen.
\end{abstract}

Keywords: HSD11B1 gene, men, metabolism, metabolic syndrome, women.

Received: February 14, 2014; Accepted: May 12, 2014.

\section{Introduction}

The HSD11B1 gene located at 1q32.2 (Tannin et al., $1991)$ encodes the microsomal enzyme $11 \beta$-hydroxysteroid dehydrogenase type 1 (11 $\beta$-HSD1) that is responsible for the conversion of the hormone cortisol (also known as stress hormone) to its metabolically inactive form cortisone (Ricketts et al., 1998). An imbalance in the levels of cortisol is associated with visceral fat, insulin resistance and hyperlipidemia, all of which are related to obesity, type 2 diabetes mellitus (T2DM) and metabolic syndrome (Paterson et al., 2004).

Various studies have suggested an important functional role of $11 \beta$-HSD1 in the metabolic processes underlying these pathologies. In knockout animals, the absence of 11ß-HSD1 had a protective effect against insulin resistance and hyperglycemia because of the lack of glucocorticoid regeneration in the liver and adipose tissue (Kotelevtsev et al., 1997; Morgan and Tomlinson, 2010). The reverse situation was seen in transgenic animals with over-

Send correspondence to Lupe Furtado Alle. Setor de Ciências Biológicas, Centro Politécnico, Departamento de Genética, Universidade Federal de Paraná, Rua Francisco H. dos Santos 210, Sala 43, 81531-970 Curitiba, PR, Brazil. E-mail: lupealle@ gmail.com. expression of 11 $\beta$-HSD1, with an increase in the concentration of intra-adipocyte glucocorticoid, hyperglycemia and a marked central obesity phenotype (Masuzaki et al., 2001). In particular, the G allele of SNP rs12086634 was associated with lower 11 $\beta$-HSD1 transcription in vitro (Draper et al., 2003).

The association between the rs 846910 polymorphism in the $\mathrm{P} 2$ promoter region and rs12086634 in an enhancer of the HSD11B1 gene has been investigated in several clinical contexts (Gambineri et al., 2011; Moon et al., 2011; Utriainen et al., 2012). In Pima Indians, these two SNPs were associated with T2DM, but not with obesity (Nair et al., 2004). Gambineri et al. (2011) found that the combination of these SNPs in Caucasian women of northern Italy was associated with a higher risk of metabolic syndrome, regardless of the diagnosis of polycystic ovary syndrome. In other studies, both SNPs were associated with T2DM and/or hypertension (Freedman et al., 2001; Goff et al., 2005).

Considering the wide range of biochemical and physiological effects of cortisol, it is possible that temporal or tissue-specific changes in the levels of this hormone could influence a wide range of complex diseases, including obesity and metabolic syndrome. Since the occurrence of genetic polymorphisms in the HS11B1 gene could influence 
cortisol levels, in this study we investigated the influence of two SNPs of the HSD11B1 gene (rs846910 and rs 12086634) on anthropometric and biochemical variables associated with obesity and metabolic syndrome in an adult population from southern Brazil.

\section{Materials and Methods}

\section{Subjects}

The sample consisted of 215 workers of Euro-Brazilian descent employed by the Federal University of Paraná in southern Brazil. Since the aim in selecting the volunteers was to obtain a sample representative of the population heterogeneity, no pathology was used as an inclusion or exclusion criterion.

One hundred and forty-seven women (22-72 years old, 56\% overweight and obese) and 68 men (23-60 years old, $23 \%$ overweight and obese) participated in the study. Assessment of the physical activity of the volunteers for seven days using a pedometer (Yamax Digi-Walker SW700 ) showed that $23 \%$ were sedentary, $37 \%$ had low physical activity, $26 \%$ were active and $14 \%$ had high physical activity [according to criteria proposed by Wyatt et al. (2005) and Tudor-Locke et al. (2011)].

Individuals were considered obese when the body mass index (BMI) was $\geq 30 \mathrm{~kg} / \mathrm{m}^{2}$ and non-obese when the BMI was $<30 \mathrm{~kg} / \mathrm{m}^{2}$. Weight and height were measured with an accuracy of $0.1 \mathrm{~kg}$ and $0.1 \mathrm{~cm}$, respectively. Glucose, triglycerides (TG), total cholesterol (TC) and HDLcholesterol (HDL-C) were measured by standard automated methods. LDL-cholesterol (LDL-C) levels were calculated using the Friedewald equation (Friedewald et al., 1972). The study was approved by the ethics committee of the Federal University of Paraná.

\section{DNA analysis}

DNA was extracted from peripheral blood by a salting-out method (Lahiri and Nurnberger Jr, 1991) and then diluted to a final concentration of $20 \mathrm{ng} / \mu \mathrm{L}$. The variant located in the P2 promoter 5'URR (rs846910; SNP1; G/A) and the variant in the enhancer region of intron 3 (rs12086634; SNP2; T/G) were genotyped with a TaqMan SNP genotyping assay (Applied Biosystems). The reactions were done in a Mastercycler Realplex 2 (Eppendorf) using the following conditions: $50{ }^{\circ} \mathrm{C}$ for $2 \mathrm{~min}, 95^{\circ} \mathrm{C}$ for $10 \mathrm{~min}$ and 50 cycles of $95^{\circ} \mathrm{C}$ for $15 \mathrm{~s}$ and $62^{\circ} \mathrm{C}$ for $1 \mathrm{~min}$. Three previously sequenced control samples, representative of each of the possible genotypes, were included in each reaction for both SNPs.

\section{Statistical analysis}

The results were expressed as the mean \pm SEM. Frequency distributions, variances, the Shapiro-Wilk normality test, Students $t$-test and the Mann-Whitney test were calculated using Statistica for Windows v. 5.0 (StatSoft Inc.
1996, Tulsa, Oklahoma). Chi-square tests were done using Clump (Sham and Curtis, 1995). Multiple regression analyses were done using SPSS for Windows v. 13.0 (SPSS Inc., Chicago, IL, USA).

\section{Results}

Table 1 shows the allele frequencies of the two SNPs in the sample stratified by sex and BMI. The genotype frequencies in the overall sample and in the groups were in Hardy-Weinberg equilibrium. There was no difference in allele frequency between obese and non-obese men $\left(\chi^{2}=0.62, p=0.43\right)$, nor between obese and non-obese women $\left(\chi^{2}=0.17, p=0.67\right)$ for SNP1. A similar result was found in comparisons between obese and non-obese men and women for SNP2 allele frequencies $\left(\chi^{2}=0.33, \mathrm{p}=0.56\right.$ and $\chi^{2}=0.67, \mathrm{p}=0.41$, respectively).

Analyses performed with the stratification of the sample only by gender, showed that there was no significant difference in the BMI of men and women $(26.87 \pm 4.00$ and $27.20 \pm 5.44$, respectively; $p=0.97$ ). However, there were significant differences in the HDL-C, TG and glucose levels of men and women, regardless of the HSD11B1 genotype $(\mathrm{p}=0.00001, \mathrm{p}=0.001$ and $\mathrm{p}=0.006$, respectively $)$ (Figure 1).

Combination analysis with the two SNPs (rs846910 and rs12086634) revealed no significant associations, in contrast to the findings of Gambineri et al. (2011). However, when the effects of each of the two HSD11B1 SNPs on the biochemical variables and BMI were analyzed separately in men and women, significant differences were found only in women (Table 2). Carriers of the A allele (rare) of SNP1 had significantly higher HDL levels when compared to individuals homozygous for the G allele (common). Similarly, carriers of the G allele (rare) of SNP2 had higher glucose levels (tending to significance, $p=0.06$ ) compared to women homozygous for the $\mathrm{T}$ allele (common). Multiple regression analysis was used to confirm the effect of these genetic variants on HDL and glucose levels (Table 3). When HDL-C was used as the dependent variable and SNP1, age and BMI as the independent variables, the analyses showed that BMI and SNP1 were independent factors in determining the HDL-C levels in women $(\beta=-0.37 \pm 0.11, p=0.002$ and $\beta=0.22 \pm 0.10, p=0.03$, respectively). Similar results were obtained when glucose was used as the dependent variable and age, BMI and SNP2 were the dependent variables, i.e., BMI and SNP2 were independent factors for increasing glucose levels $(\beta=0.46 \pm$ $0.10, p=0.00002$ and $\beta=0.19 \pm 0.09, p=0.03$, respectively).

\section{Discussion}

The importance of gender differences in molecular biology is being increasingly recognized. Cellular re- 
Table 1 - Allele frequencies (\%) of SNPs 1 and 2 of the HSD1 1 B 1 gene in samples stratified by sex (men and women) and BMI (obese and non-obese).

\begin{tabular}{|c|c|c|c|c|}
\hline \multirow[b]{2}{*}{ SNP } & \multicolumn{2}{|c|}{ Men } & \multicolumn{2}{|c|}{ Women } \\
\hline & Obese $(n=16)$ & Non-obese $(\mathrm{n}=52)$ & Obese $(n=38)$ & Non-obese $(n=109)$ \\
\hline \multicolumn{5}{|c|}{ SNP1: rs846910 } \\
\hline Allele A & $6.1 \pm 4$ & $11.0 \pm 3$ & $6.9 \pm 2$ & $8.5 \pm 1$ \\
\hline Allele G & $93.8 \pm 4$ & $89.0 \pm 3$ & $93.0 \pm 2$ & $91.5 \pm 1$ \\
\hline \multicolumn{5}{|c|}{ SNP2:rs 12086634} \\
\hline Allele G & $15.6 \pm 6$ & $20.1 \pm 3$ & $18.4 \pm 4$ & $22.9 \pm 2$ \\
\hline AlleleT & $84.4 \pm 6$ & $79.8 \pm 3$ & $81.6 \pm 4$ & $77.1 \pm 2$ \\
\hline
\end{tabular}

The results are expressed as the mean $\% \pm$ SEM. Obese individuals: $\mathrm{BMI} \geq 30 \mathrm{~kg} / \mathrm{m}^{2}$; non-obese individuals: $\mathrm{BMI}<30 \mathrm{~kg} / \mathrm{m}^{2}$.

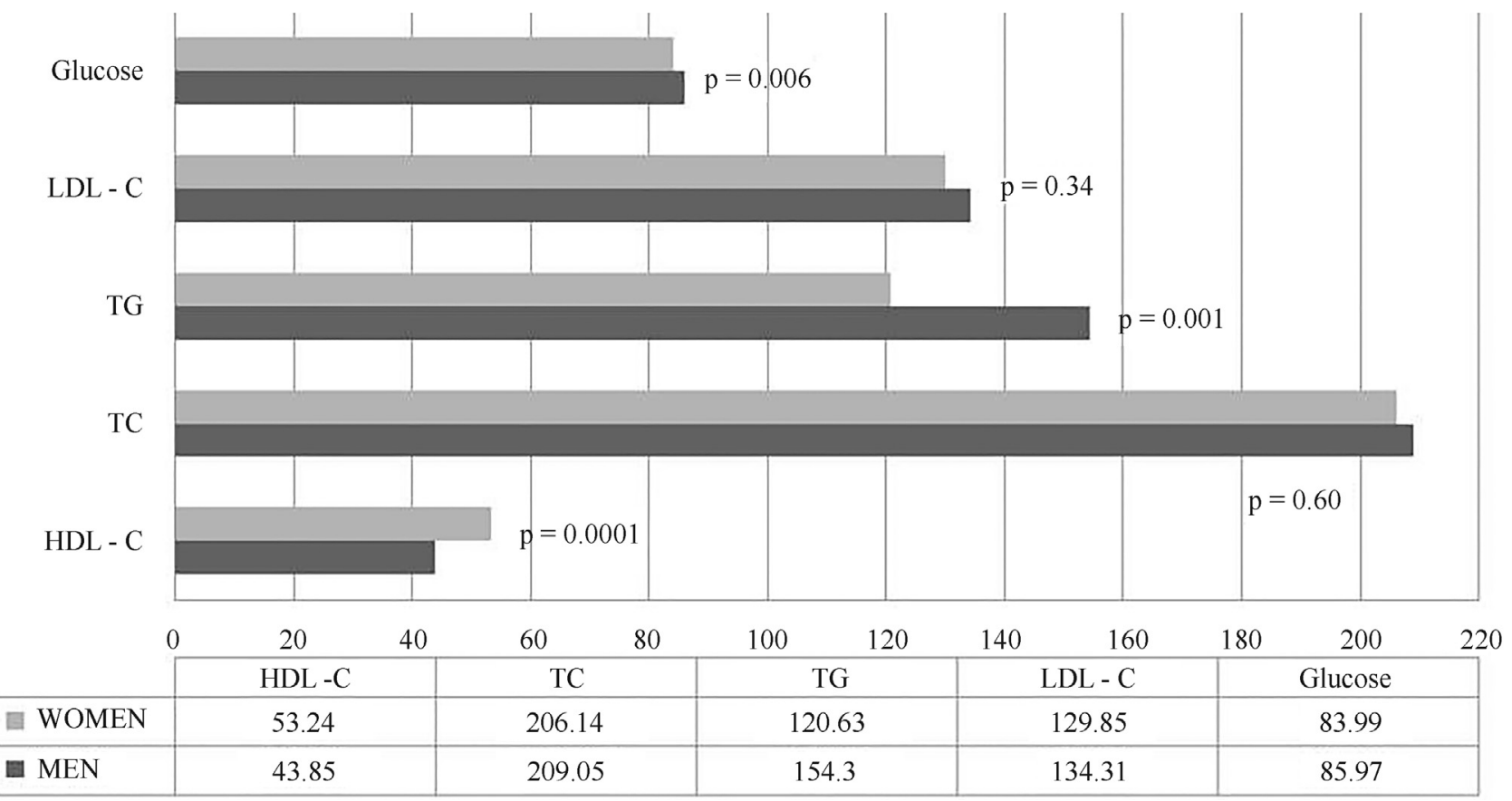

Figure 1 - HDL-C, TC, TG, LDL-C and glucose levels in men and women. The columns represent the mean of 68 men and 147 women. All values are expressed in $\mathrm{mg} / \mathrm{dl}$. Statistical comparisons were done using Students $t$-test.

sponses to stress, even before exposure to sex hormones, are different in men and women (Du et al., 2004) and probably reflect gender-related differences in metabolic pathways (Pollitzer, 2013). Indeed, the higher prevalence of obesity and diabetes in women compared to men, especially after the onset of menopause (Ryan, 2009), indicates that gender-related metabolic differences can influence the mechanisms of these diseases. The greater amount of visceral fat and higher fat content in the liver correlate with the lack of a protective effect of estrogen in premenopausal women (Geer and Shen, 2009). However, the effect of estrogen on the metabolism of adipose tissue is not fully understood. Premenopausal women have a higher density of antilipolytic $\alpha_{2}$-adrenergic receptors than men (Richelsen, 1986). Pedersen et al. (2004) demonstrated that estradiol increases the expression of this receptor in human adipo- cytes through activation of ER- $\alpha$ receptors only in subcutaneous adipose tissue, with no effect on visceral adipose tissue. Estradiol thus favors the deposition of subcutaneous fat at the expense of visceral deposition. The activity of LPL (lipoprotein lipase), which controls fat uptake in adipocytes, is also influenced by estradiol since this hormone has transcriptional inhibitory effects (Homma et al., 2000) and decreases the transcription and enzymatic activity of $11 \beta$-HSD1 in rodents (New et al., 2000). Postmenopausal women with normal weight show enhanced $11 \beta-H S D 1$ activity in adipose tissue and liver (Andersson et al., 2009), suggesting that low estrogen levels may up-regulate $11 \beta$ HSD1 activity and contribute to the imbalance of energy metabolism influenced by cortisol. In a study of inflammatory bowel disease, 11 $\beta$-HSD1 expression was higher in 
Table 2 - -Comparison of the BMI, HDL-C, TC, TG, LDL-C and glucose levels in men and women stratified as carriers of common (G or T) or rare (A or G) alleles of SNPs 1 and 2.

\begin{tabular}{|c|c|c|c|c|c|c|}
\hline \multirow{2}{*}{$\begin{array}{l}\text { SNP } \\
\text { SNP1: rs } 846910\end{array}$} & \multicolumn{3}{|c|}{ Men } & \multicolumn{3}{|c|}{ Women } \\
\hline & $\begin{array}{l}\text { A allele carriers } \\
\quad(n=13)\end{array}$ & Non-carriers $(\mathrm{n}=55)$ & $\mathrm{p}$ & $\begin{array}{l}\text { A allele carriers } \\
\quad(n=21)\end{array}$ & Non-carriers $(n=126)$ & $\mathrm{p}$ \\
\hline BMI $\left(\mathrm{kg} / \mathrm{m}^{2}\right)$ & $26.21 \pm 3.76$ & $27.05 \pm 4.22$ & 0.51 & $26.57 \pm 4.85$ & $27.20 \pm 5.42$ & 0.61 \\
\hline $\mathrm{HDL}(\mathrm{mg} / \mathrm{dL})$ & $45.83 \pm 9.06$ & $43.22 \pm 9.13$ & 0.37 & $59.65 \pm 16.29$ & $50.94 \pm 14.74$ & 0.03 \\
\hline $\mathrm{TC}(\mathrm{mg} / \mathrm{dL})$ & $215.83 \pm 23.72$ & $209.42 \pm 36.91$ & 0.56 & $202.40 \pm 53.49$ & $205.77 \pm 35.34$ & 0.71 \\
\hline $\mathrm{TG}(\mathrm{mg} / \mathrm{dL})$ & $156.91 \pm 45.14$ & $156.83 \pm 86.99$ & 0.51 & $124.40 \pm 70.08$ & $117.85 \pm 60.68$ & 0.83 \\
\hline LDL (mg/dL) & $139.41 \pm 21.69$ & $132.14 \pm 37.48$ & 0.52 & $123.58 \pm 39.59$ & $130.18 \pm 29.99$ & 0.39 \\
\hline \multirow[t]{2}{*}{ Glucose (mg/dL) } & $86.91 \pm 7.25$ & $86.07 \pm 9.72$ & 0.60 & $88.95 \pm 40.88$ & $80.97 \pm 18.73$ & 0.33 \\
\hline & \multicolumn{3}{|c|}{ Men } & \multicolumn{3}{|c|}{ Women } \\
\hline SNP2: rs12086634 & $\begin{array}{c}\mathrm{G} \text { allele carriers } \\
\quad(\mathrm{n}=24)\end{array}$ & Non-carriers $(n=44)$ & $\mathrm{p}$ & $\begin{array}{l}\text { G allele carriers } \\
\quad(\mathrm{n}=58)\end{array}$ & Non-carriers $(\mathrm{n}=89)$ & $\mathrm{p}$ \\
\hline BMI $\left(\mathrm{kg} / \mathrm{m}^{2}\right)$ & $26.04 \pm 3.90$ & $27.33 \pm 4.11$ & 0.20 & $27.44 \pm 5.30$ & $27.05 \pm 5.53$ & 0.67 \\
\hline HDL (mg/dL) & $44.27 \pm 7.85$ & $43.71 \pm 9.62$ & 0.81 & $51.43 \pm 14.23$ & $54.34 \pm 13.34$ & 0.23 \\
\hline $\mathrm{TC}(\mathrm{mg} / \mathrm{dL})$ & $206.50 \pm 25.73$ & $209.20 \pm 38.72$ & 0.76 & $202.07 \pm 39.60$ & $208.61 \pm 38.27$ & 0.34 \\
\hline $\mathrm{TG}(\mathrm{mg} / \mathrm{dL})$ & $138.81 \pm 61.08$ & $157.60 \pm 78.82$ & 0.33 & $116.92 \pm 51.93$ & $122.89 \pm 64.22$ & 0.92 \\
\hline $\mathrm{LDL}(\mathrm{mg} / \mathrm{dL})$ & $134.90 \pm 22.75$ & $133.90 \pm 34.90$ & 0.90 & $129.68 \pm 29.77$ & $129.95 \pm 33.27$ & 0.77 \\
\hline Glucose $(\mathrm{mg} / \mathrm{dL})$ & $84.72 \pm 7.56$ & $86.64 \pm 9.84$ & 0.42 & $85.39 \pm 16.20$ & $83.14 \pm 21.47$ & 0.06 \\
\hline
\end{tabular}

The data are expressed as the mean \pm SEM of the number of individuals indicated in parentheses. Statistical comparisons between men and women (stratified by genotype) were done using Students $t$-test $(t)$ for parametric data and the Mann-Whitney test (Z) for non-parametric data. Significant differences (p) are indicated in bold.

Table 3 - Results of the multiple regression analysis.

\begin{tabular}{lcccc}
\hline Dependent variable & $\begin{array}{c}\text { Independent variable } \\
\text { considered }\end{array}$ & $\begin{array}{c}\text { Independent variable } \\
\text { confirmed }\end{array}$ & $\beta \pm$ SEM & $p$ \\
\hline HDL-C levels & SNP1, age and BMI & BMI and SNP1 & $(-0.37 \pm 0.11)$ and $(0.22 \pm 0.10)$, respec- & 0.002 and 0.03 , respectively \\
Glucose levels & SNP2, age and BMI & BMI and SNP2 & $(0.46 \pm 0.10)$ and $(0.19 \pm 0.09)$, respec- & 0.00002 and 0.03 , respectively \\
\end{tabular}

male than in female patients, whereas 11 $\beta$-HSD2 showed not gender-specific regulation in its expression (Stegk et al., 2009).

As shown here, only in women was the presence of the rare SNP2 allele associated with higher glucose levels, whereas women homozygous for the common SNP1 allele showed lower HDL-C levels compared to rare allele carriers. The combination of higher glucose levels and lower HDL-C levels may have an important role in the development of pathologies associated with obesity. Lower than normal levels of HDL-C have been related to the early development of T2DM (Von Eckardstein et al., 2000), and conditions such as insulin resistance and obesity may also be related to lower HDL-C levels and to the generation of small particles of HDL-C that can result in several functional changes (Goff et al., 2005).

Men and woman show different responses to the same food intake. Compared to women, men have higher levels of postprandial insulin and TG (Cohn et al., 1988), suggest- ing that estrogen also has a beneficial effect on TG levels in response to food ingestion (Westerveld, 1998). The sexual dimorphism in TG levels was striking in our study: women had a normal mean TG level, whereas men had a borderline mean TG level, based on age- and gender-related reference values for TG.

Since the women in this study were more sensitive to the effects of the HSD11B1 gene polymorphisms investigated here, it is possible that such variations influence the modulation established between estrogen and 11 $\beta$-HSD1. The presence of the two SNPs may alter the downregulation caused by estrogen and possibly lead to an imbalance in the metabolic pathways involved in glucose and fat metabolism.

Divergent results have been reported for the effect of these variants on HSDI1B1 expression. The G allele of SNP rs 12086634 was associated with lower transcriptional activity in vitro (Draper et al., 2003), whereas the less frequent allele combination (A and G) for these two SNPs 
(rs846910 and rs12086634, respectively) was associated with higher mRNA levels and 11 $\beta$-HSD1 activity in adipose tissue in southern European Caucasian women with and without polycystic ovary syndrome (PCOS) (Gambineri et al., 2011). Other studies found no relationship between one or both variants and 11/-HSD1 levels (Nair et al., 2004; Millan et al., 2005; White, 2005; Malavasi et al., 2010). The genetic variants investigated here may have increased the HSDI1B1 transcriptional levels, leading to an imbalance of homeostasis via estradiol down-regulation in women. A similar effect was not detected in males, suggesting that mechanisms other than estradiol suppress the influence of these genetic polymorphisms on the metabolic variables investigated in this study.

Such polymorphisms may represent only a minor contribution to the mechanisms underlying this imbalance. Our results showed that the SNPs and BMI had an independent effect on glucose and HDL-C levels in women, although other factors need to be considered. Other variables such as smoking (Brischetto et al., 1983), abdominal fat distribution (Ostlund et al., 1990) and aerobic exercise training (Kokkinos and Fernhall, 1999) have also been related to HDL-C levels. Moreover, a decline in HDL-C levels simultaneous to the decline in estrogen levels in post-menopausal woman has been described ( $\mathrm{Li}$ et al., 1996; Senoz et al., 1996; Pasquali et al., 1997); insulin and glucose levels have also been related to HDL-C, which suggests an influence of carbohydrate metabolism and sex hormone status on the levels of this lipoprotein (Sowers and Sigler, 1999).

Among the limitations of this study was the sample size, which may not have been large enough to detect any other significant results. In addition, a functional relationship between the variants studied would be better established in a case-control study, especially with postmenopausal women.

In conclusion, we found that the SNPs investigated here acted as independent factors in determining glucose and HDL-C levels only in women. This finding suggested a potentially important sexually dimorphic effect that may be related to gene regulation exerted by estrogen.

\section{Acknowledgments}

This work was supported by CAPES and Fundação Araucaria.

\section{References}

Andersson T, Simonyte K, Andrew R, Strand M, Burén J, Walker BR, Mattson C and Olsson T (2009) Tissue-specific increases in $11 \beta$-hydroxysteroiddehydrogenase type 1 in normal weight postmenopausal women. PLoS One 4:e8475.

Brischetto CS, Connor WE, Connor SL and Matarazzo JD (1983) Plasma lipid and lipoprotein profiles of cigarette smokers from randomly selected families: Enhancement of hyperli- pidemia and depression of high-density lipoprotein. Am J Cardiol 52:675-680.

Cohn JS, McNamara JR, Cohn SD, Ordovas JM and Schaefer EJ (1988) Post-prandial plasma lipoprotein changes in human subjects of different ages. Lipid Res 29:469-479.

Draper N, Walker EA, Bujalska IJ, Tomlinson JW, Chalder SM, Arlt W, Lavery GG, Bedendo O, Ray DW, Laing I, et al. (2003) Mutations in the genes encoding 11-hydroxysteroid dehydrogenase type 1 and hexose-6-phosphate dehydrogenase interact to cause cortisone reductase deficiency. Nat Genet 34:434-439.

Du L, Bayir H, Lai Y, Zhang X, Kochanek PM, Watkins SC, Graham SH and Clark RS (2004) Innate gender-based proclivity in response to cytotoxicity and programmed cell death pathway. J Biol Chem 279:38563-38570.

Freedman DS, Bowman BA, Srinivasan SR, Berenson GS and Otvos JD (2001) Distribution and correlates of high-density lipoprotein subclasses among children and adolescents. Metabolism 50:370-376.

Friedewald WT, Levy RI and Fredrickson DS (1972) Estimation of the concentration of low-density lipoprotein cholesterol in plasma, without use of the preparative ultracentrifuge. Clin Chem 18:499-502.

Gambineri A, Tomassoni F, Munarini A, Stimson RH, Mioni R, Pagotto U, Chapman KE, Andrew R, Mantovani V, Pasquali $\mathrm{R}$, et al. (2011) A combination of polymorphisms in HSD11B1 associates with in vivo $11 \beta-H S D 1$ activity and metabolic syndrome in women with and without polycystic ovary syndrome. Eur J Endocrinol 165:283-292.

Geer EB and Shen W (2009) Gender differences in insulin resistance, body composition, and energy balance. Gend Med 6:60-75.

Goff DC, D'Agostino Jr RB, Haffner Jr SM and Otvos JD (2005) Insulin resistance and adiposity influence lipoprotein size and subclass concentrations. Results from the insulin resistance atherosclerosis study. Metabolism 54:264-270.

Homma H, Kurachi H, Nishio Y, Takeda T, Yamamoto T, Adachi $\mathrm{K}$, Morishige K, Ohmichi M, Matsuzawa Y and Murata Y (2000) Estrogen suppresses transcription of lipoprotein lipase gene. Existence of a unique estrogen response element on the lipoprotein lipase promoter. J Biol Chem 275:1140411411.

Kokkinos PF and Fernhall B (1999) Physical activity and high density lipoprotein cholesterol levels: What is the relationship? Sports Med 28:307-314.

Kotelevtsev Y, Holmes MC, Burchell A, Houston PM, Schmoll D, Jamieson P, Best R, Brown R, Edwards CR, Seckl JR, et al. (1997) 11ß-Hydroxysteroid dehydrogenase type 1 knockout mice show attenuated glucocorticoid-inducible responses and resist hyperglycemia on obesity or stress. Proc Natl Acad Sci USA 94:14924-14929.

Lahiri DK and Nurnberger Jr JI (1991) A rapid non-enzymatic method for the preparation of HMW DNA from blood for RFLP studies. Nucleic Acids Res 19:5444.

Li Z, McNamara JR, Fruchart JC, Luc G, Bard JM, Ordovas JM, Wilson PW and Schaefer EJ (1996) Effects of gender and menopausal status on plasma lipoprotein subspecies and particle sizes. J Lipid Res 37:1886-1889.

Malavasi ELV, Kelly V, Nath N, Gambineri A, Dakin RS, Pagotto U, Pasquali R, Walker BR and Chapman KE (2010) Functional effects of polymorphisms in the human gene encoding 
11-hydroxysteroid dehydrogenase type1 (11-HSD1): A sequence variant at the translation start of 11-HSD1 alters enzyme levels. Endocrinology 151:195-202.

Masuzaki H, Paterson J, Shinyama H, Morton NM, Mullins JJ, Seckl JR and Flier JS (2001) A transgenic model of visceral obesity and the metabolic syndrome. Science 294:21662170.

Millan JL, Botella-Carratero JI, Alvarez-Blasco F, Luque-Ramirez M, Sancho J, Moghetti P and Escobar-Morreal HF (2005) A study of the hexose-6-phosphate dehydrogenase gene R453Q and 11 $\beta$-hydroxysteroid dehydrogenasetype1 gene 83557insA polymorphisms in the polycystic ovary syndrome. J Clin Endocrinol Metab 90:4157-4162.

Moon SS, Lee YS, Kim JG, Kim SW, Jeong JY, Jeon EJ, Seo HA, Kwak SH, Park KS and Lee IK (2011) Relationship of 11ß-hydroxysteroid dehydrogenase type 1 and hexose-6phosphate dehydrogenase gene polymorphisms with metabolic syndrome and type 2 diabetes. Endocr J 58:949-959.

Morgan SA and Tomlinson JW (2010) 11ß-hydroxysteroid dehydrogenase type 1 inhibitors for the treatment of type 2 diabetes. Expert Opin Investig Drugs 19:1067-1076.

Nair S, Lee YH, Lindsay RS, Walker BR, Tataranni PA, Bogardus C, Baier LJ and Permana PA (2004) 11-Hydroxysteroid dehydrogenase type 1: Genetic polymorphisms are associated with type 2 diabetes in Pima Indians independently of obesity and expression in adipocyte and muscle. Diabetologia 47:1088-1095.

New KH, Hamid A, Morat PB and Khalid BA (2000) Differential regulation of the oxidative $11 \beta$-hydroxysteroid dehydrogenase activity in testis and liver. Steroids 65:40-45.

Ostlund RE, Staten M, Kohrt WM, Schult J and Malley M (1990) The ratio of waist-to-hip circumference, plasma insulin level, and glucose intolerance as independent predictors of the HDL2 cholesterol level in older adults. N Engl J Med 322:229-234.

Pasquali R, Casimirri F, Pascal G, Tortelli O, Morselli-Labate A, Bertazzo D, Vicennati V and Gaddi A (1997) Influence of menopause on blood cholesterol levels in women: The role of body composition, fat distribution, and hormonal milieu. J Intern Med 24:195-203.

Paterson JM, Morton NM, Fievet C, Kenyon CJ, Holmes MC, Staels B, Seckl JR and Mullins JJ (2004) Metabolic syndrome without obesity: Hepatic overexpression of $11 \beta$-hydroxysteroid dehydrogenase type 1 in transgenic mice. Proc Natl Acad Sci USA 101:7088-7093.

Pedersen SB, Kristensen K, Hermann PA, Katzenellenbogen JA and Richelsen B (2004) Estrogen controls lipolysis by upregulating $\alpha_{2 \mathrm{~A}}$-adrenergic receptors directly in human adipose tissue through the estrogen receptor $\alpha$. Implications for the female fat distribution. J Clin Endocrinol Metab 89:1869-1878.

Pollitzer E (2013) Cell sex matters. Nature 500:23-24.

Richelsen B (1986) Increased $\alpha_{2}$ - but similar $\beta$-adrenergic receptor activities in subcutaneous gluteal adipocytes from females compared with males. Eur J Clin Invest 16:302-309.
Ricketts ML, Verhaeq JM, Bujalska I, Howie AJ, Rainey WE and Stewart PM (1998) Immunohistochemical localization of type $111-\beta$-hydroxysteroid dehydrogenase in human tissues. J Clin Endocrinol Metab 83:1325-1335.

Ryan JG (2009) Cost and policy implications from the increasing prevalence of obesity and diabetes mellitus. Gend Med 6:86-108.

Senoz S, Direm B, Gulecki B and Gokmen O (1996) Estrogen deprivation, rather than age, is responsible for the poor lipid profile and carbohydrate metabolism in women. Maturitas 25:107-114.

Sham PC and Curtis D (1995) Monte Carlo tests for associations between disease and alleles at highly polymorphic loci. Ann Hum Genet59:97-105.

Sowers MF and Sigler C (1999) Complex relation between increasing fat mass and decreasing high density lipoprotein cholesterol levels: Evidence from a population-based study of premenopausal women. Am J Epidemiol 149:47-54.

Stegk JP, Ebert B, Martin H-J and Maser E (2009) Expression profiles of human 11 $\beta$-hydroxysteroid dehydrogenases type 1 and type 2 in inflammatory bowel diseases. Mol Cell Endocrinol 301:104-108.

Tannin GM, Agarwal AK, Monder C, New MI and White PC (1991) The human gene for 11- $\beta$-hydroxysteroid dehydrogenase: Structure, tissue distribution, and chromosomal localization. J Biol Chem 266:16653-16658.

Tudor-Locke C, Craig CL, Brown WJ, Clemes AS, De Cocker K, Giles-Corti B, Hatano Y, Inoue S, Matsudo SM, Mutrie N, et al. (2011) How many steps/day are enough for adults? Int J Behav Nutr Phys Act 8:79.

Utriainen P, Laakso S, Jääskeläinen J and Voutilainem R (2012) Polymorphisms of POR, SULT2A1 and HSD11B1 in children with premature adrenarche. Metabolism 61:1215-1219.

Von Eckardstein A, Schulte H and Assmann G (2000) Risk for diabetes mellitus in middle-aged Caucasian male participants of the PROCAM study: Implications for the definition of impaired fasting glucose by the American Diabetes Association. Prospective Cardiovascular Munster. J Clin Endocrinol Metab 85:3101-3108.

Westerveld HE (1998) Estrogens and postprandial lipid metabolism. Atherosclerosis 141:105-107.

White PC (2005) Genotypes at 11 $\beta$-hydroxysteroid dehydrogenase type 11B1 and hexose-6-phosphate dehydrogenase loci are not risk factors for apparent cortisone reductase deficiency in a large population-based sample. J Clin Endocrinol Metab 90:5880-5883.

Wyatt HR, Peters JC, Reed GW, Barry M and Hill JO (2005) A Colorado statewide survey of walking and its relation to excessive weight. Med Sci Sports Exerc 37:724-730.

Associate Editor: Mara H. Hutz

License information: This is an open-access article distributed under the terms of the Creative Commons Attribution License, which permits unrestricted use, distribution, and reproduction in any medium, provided the original work is properly cited. 